\title{
At the Crossroads: Assessing and responding to chomge
}

\section{Highlights of ACRL programs at ALA's Annual Conference: Part I}

$\mathbf{A}$

djusting to change, making room for multiculturalism, and assuring continued progress, both technological and social were some of the issues covered by ACRL at ALA's 112th Annual Conference in New Orleans. Highlights of some ACRL programs are given below; part two will appear in October. See the accompanying sidebar for information in ordering audiotapes of selected programs.

\section{Change in academe}

The ACRL President's Program was the culmination of Jacquelyn McCoy's theme of academic libraries at the crossroads. Two presenters responded to the program topic, "Headed for the Beach? Redirecting the Academic Whale." Professor Robert Zemsky, director of the Institute for Research in Higher Education at the University of Pennsylvania and Dr. Carole A. Barone, associate vicechancellor at the University of California-Davis, both extolled the need for change to come from within academe, and, by extension, from within our libraries.

Zemsky said "there are no villains. Them is us." $\mathrm{He}$ added the we will be the villains if we ignore the need to change. Academia isn't "special" anymore; we are part of an enterprise and we need to market our services to please our users. He used two analogies from the business sector to illustrate his point: tailored mail-order catalogs over a comprehensive Sears catalog and automatic teller machines over trips to the bank. He concluded that the market shapes our research agenda.
Barone used a multi-media presentation to dramatize her point: "change or be isolated." Among her list of 12 statements to consider were: listening to what users want (like Burger King); asking "how to" instead of "why not"; doing something different, not doing less; and collaborating with our publics because the Lone Ranger is obsolete. Both speakers emphasized bringing the clients into the process. During the business meeting which preceded the program, Euster, who is also chair of the next ACRL National Conference, announced that "change" will also be part of that conference theme to be held March 29 through April 1, 1995, in Pittsburgh. Anne Beaubien, past president of ACRL reported on the final report of the Social Issues Task Force, and Vice-President Thomas Kirk announced his theme of "networking" for the coming year.

The program ended with a delightful video of the life of William Andrew Moffett, recipient of the 1992-93 Academic/Research Librarian of the Year Award. Moffett, director of the Huntington Library, was recognized for his action in providing scholars with access to the Dead Sea Scrolls. A reception for him hosted by Baker \& Taylor followed.Barbara Wittkopf, Louisiana State University

\section{Assessing three decades of progress}

The Afro-American Studies Librarians Section of ACRL presented "Afro-American Information Resources: Assessing Three Decades of Progress, 1960-1990", in co-sponsorship with the Anthropology and Sociology, and the Asian and African Studies Sections. Keynote speaker, Dr. Bennie Reeves, acting president and professor of history at Florida Memorial College in Miami, began by stating that early scholarship 
on blacks had been complex, racist, and presumptuous, perpetuating the negative image that society projected. It was only when black scholars, such as John Hope Franklin, Benjamin Quarles and John Henrik Clarke began publishing did historical literature focused on blacks begin to take a more positive and honest stance. Citing several titles, Reeves cogently argued that the proliferation of materials on blacks was closely connected to the political and social movements of the time. He maintained that the civil rights era and the Black Power Movement ushered in a new focus that examined black roles in the 1960 s and 1970 s bringing with it not only new literature, but the birth of third world publishing companies sensitive to the needs of a Black population. Reeves chal-

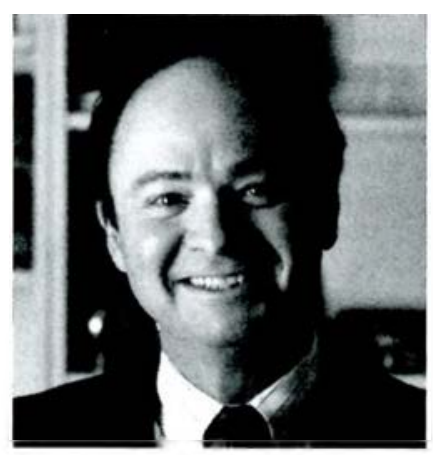

Robert Zemsky stressed the importance of marketing.

\section{A different view of historic preservation}

The ACRL Arts Section and the Rare Books and Manuscripts Section (RBMS) jointly sponsored a program entitled "Balconies and Verandas: Documentation and Preservation of New Orleans Architecture." Each of the four speakers, discussed the preservation of New Orleans architecture from a different perspective.

Sally K. Reeves, archivist of the New Orleans Notarial Archives, discussed a unique resource available to architectural historians in New Orleans. Because Louisiana's legal system is based on the civil law brought there by the French and Spanish, each legal transaction must be documented by a third and impartial party, the notary. The Notarial Archives were be- lenged black librarians to create special collaborative projects to document and preserve black history, and encourage scholars to use repositories such as the Amistad Research Center, the Moorland-Spingarn Collection at Howard University and the Schomburg Library in New York.

Brenda Mitchell-Powell, editor of Multicultural Review and a member of the reactor panel, addressed the lack of control African Americans have historically had over material published relating to them. She asserted that African Americans have been "victims of the commodification of culture." She implored black librarians and scholars to "wrest back control of our literature" and reminded the audience of the plight of our literature if we failed in this mission. She stated that several seminal works have never been revised or have gone quickly out-of-print. Too often original publishers have not republished works that may have been controversial in nature, such as works by J. A. Rogers, Chancellor Williams, and Ivan Van Sertima. Mitchell-Powell concluded by asking that African American librarians be especially diligent in challenging the publishing companies to provide timely revisions of reference sources to keep pace with scholarship, and to reconsider works that are destined for out-of-print status.-Deborab A. Curry, University at Albany gun in the 1730 s and now contain 38,000 volumes of notarial acts, documenting such transactions as building contracts, sales and emancipations of slaves, wills, and marriage contracts. The great value of these archives to architectural historians results from the fact that each sale of real property included complete watercolor drawings of the buildings by the civil engineer who examined the property. After 1910, blueprints rather than watercolors were attached to the legal documents.

During the 1930s, the WPA undertook a project with the archives that has led to many problems. The watercolor drawings were removed from their original place in the archives, separated from the written descriptions of the properties, and in many cases badly repaired.

Reeves recently received a grant from the National Endowment for the Humanities to repair these documents, purchase cabinets to hold them, and to create a database for access to them. The wealth of information in these archives offers architectural historians an opportunity to study individual detailed drawings of the many architectural styles-Georgian, neoclassical, neo-Egyptian and, of course, Frenchthat were built in this multicultural city.

Samuel Wilson, member of the architectural firm of Koch and Wilson, who gave an overview of New Orleans architecture. Patty Gaye, executive director of the Preservation Resource 
Center, commented on the efforts of her organization to preserve New Orleans including het program "Live in a Landmark" which encourages individuals to buy, restore, and live in historic properties. Jesse Poesch, retired professor of art history at Tulane University, spoke of the various resources that can be used in scholarly research about architectural history.-Betty Bryce, University of Alabama

\section{Standards at the crossroads}

The panel discussion "Standards at the Crossroads" scrutinized the accreditation process in relation to ACRL's standards for academic libraries. Sponsored by the Community and Junior College Libraries Section, College Libraries

\section{". . . in the 1950s methods of}

measuring procedures were

developed on the premise that, if it walks like a duck, it must be a duck. In the 1980s interest in educational reform produced expectations of change in the way the duck walks."

Section, and University Libraries Section, panelists discussed the value of quantitative measurements. Can qualitative outcomes be assessed meaningfully? If regional accreditation organizations ignore ACRL's standards, why do librarians pursue them?

Charles Atwell, vice president of Pensacola Jr. College, noted that in the 1950 s methods of measuring procedures were developed on the premise that, if it walks like a duck, it must be a duck. In the 1980 s interest in educational reform produced expectations of change in the way the duck walks. In responding to a question, Atwell observed that administrators need help with accreditation issues. If librarians reach a consensus concerning library standards, they will be in a much better position in relation to others who will also demand attention and money. Marcia J. Myers, director of libraries at Eastern Kentucky University, stated that North Central Association is the only one of the seven regions to acknowledge the library standards. She added that if professionally prepared standards were not available, "we would run the risk that outsiders would do it for us." Antoinette M. Kania, dean of libraries at Suffolk Community College, noted that the regional organizations have changed since her 1984 study of them. Now emphases are on links among academic libraries, other resources and instructional programs, on delivery of services, and on supportive data to demonstrate effectiveness. David B. Walch, dean of library services at California Polytechnic University, in studying use of the College Library Standards found that most of those surveyed prefer quantitative criteria.Rebecca B. Kiel, Cottey College

\section{For richer or poorer: Library development and special collections}

The Rare Books and Manuscripts Section's program, cosponsored by LAMA's Fundraising and Financial Development Section, featured four speakers: Lynda Claasen, University of California, San Diego; Myrna K. Jackson, Duke University; $\mathbf{H}$. Thomas Hickerson, Cornell University, and Barbara Dewey, University of Iowa. Three common themes emerged. First, the success of a development program depends heavily on strong, daring leadership. Second, development programs must continually seek new donors. Third, while special collections is often the focus of fundraising efforts, the entire library benefits.

Lynda Claasen spoke from the perspective of a director of special collections who also serves as the library's development officer. She emphasized special collections directors' talents in working with friends groups, donors and grants. "In practically every case, what's good for the library is good for special collections and we're well positioned to make the good happen," she concluded.

Myrna Jackson, who went from a general university development office to the library, focused on three key words, "prospects, prospects, prospects." She characterized the library development officer's dilemma: "those who read don't have money to give, those who have money don't have time to read." Jackson spoke about using the resources of special collections to attract gifts which fund a broad range of library needs. She offered the image of "hitch[ing] our less glamorous need to the glorious horse of special collections."

Tom Hickerson presented the point of view of a special collections director at a university which is highly successful in fundraising. One of his themes was special collections staff's 


\section{Moving toward confluence: Report on planning for the ACRL 7th National Conference, 1995}

"Continuity and Transformation: The Promise of Confluence" is the theme for the Seventh National Conference of ACRL, which will be held in Pittsburgh, March 29 through April 1, 1995.

The conference executive committee, meeting for the second time in New Orleans in June, considered suggestions and advice from a wide spectrum of the ACRL membership before deciding on this theme and reviewing it with the ACRL Board of Directors.

As at prior national conferences, the programs will include an energetic mix of theme speakers of national prominence, research papers, panel programs, poster sessions, and exhibits. A full menu of social and cultural events unique to Pittsburgh is in the planning, as is ample time for less formal interaction among colleagues.

heavy involvement in development. He pointed out that, with the growth of a library development unit, the special collections development program ceased as an independent activity, and he chronicled some of the effects this has had on special collections.

Barbara Dewey, a library administrator whose area of responsibility includes development, spoke about several programs of the lowa Women's Archives. In what was surely the first RBMS program address to mention Madonna, Dewey described how an Archives founder sold a Frida Kahlo self-portrait to kick off fundraising. (Madonna almost bought the painting.) Dewey stressed the need to build a multi-dimensional development program which will attract new donors to the library. She also suggested that goodwill is nearly as important a benefit as is a tangible gift.-Suzy Taraba, Duke University

\section{New resources east of the former Iron Curtain}

Eastern European independent states have thrown open a treasury of resources in all disciplines, said Edward Kasinec, chief of the Slavic Baltic Division at the New York Public Library, and first speaker at the joint program of ACRL's Western European Specialists Section and
The National Conference Executive Committee is composed of the chairs of each of the conference subcommittee: preconferences, Cathy Henderson, University of Texas-Austin: local arrangements, Charles Lowry, Carnegie Mellon University; poster sessions, Tom Peischl, Mankato State University; contributed papers, Marion Reid, California State University, San Marcos; theme speakers, Patricia Wand, American University; panel programs, Sarah Watstein, Virginia Commonwealth University; and chair, Joanne Euster, University of California, Irvine. Each subcommittee chair appoints members from all types of academic libraries and in a broad spectrum of positions to assist with planning.

look for further information and future announcements as plans unfold. We look forward to seeing you at the conference.-Joanne $R$. Euster, chair ACRL Seventh National Conference, JREUSTER@uci.edu

ACRL's Slavic and East European Section: "Europe East \& West: New Resources for North American Libraries." Increasingly, area specialists are called to serve as a broadly interdisciplinary match-maker between subject specialists or researchers and newly emerging materials available east of the former Iron Curtain. Sem Sutter, bibliographer for Western European Languages and Literatures at the University of Chicago, enumerated specific archives that German reunification has made accessible, e.g., Prussian "Secret" State Archives, Deutsche Bank archives, and documents of the East German secret police. He then outlined problems of "trophy literature," materials exappropriated to Germany illegally from the Soviet Union during and after World War II and vice versa (a church at Uzkoye, outside Moscow, has chaotic stacks of over one million books taken from Germany). Biblio-repatriation can be negotiated, Sutter stated, but inevitably revolves around hard currency. Michael Miller, Germans from Russia Bibliographer at North Dakota State University, having himself descended from a branch of the German-Russian family tree, illustrated access to it with a slide presentation. Miller pinpointed far-flung pockets of ethnic records documenting the Germans from Rus- 
sia, e.g., St. Petersburg; Stuttgart; Lincoln, Nebraska; Salt Lake City; and his own unique collection in Fargo.

Norman Ross served as a relevant discussant due to his own recent and continuing work at microfilming Slavic records. In this capacity, he has enjoyed the consultation of Mr. Kasinec. The final perspective Ross offered was one borrowed from a Pete Seeger folk tune, seeing earth from the cosmos and realizing that we're all sharing one little globe. The more information we can find and discribute, Ross suggested, the better our chances of sharing this earth in peace. -Richard Hacken, Brigham Young University

\section{Organizational transformation: New structures for new realities}

On June 26 in the New Orleans Conference Center, a large audience listened to Susan Jurow of the Association of Research Libraries, Cecilia Knight of the University of Arizona, Deborah Babel of Clemson University, and Marion Reid of California State University at San Marcos.

The organizational changes occurring in academic libraries were examined from several perspectives, Susan Jurow discussed the theoretical basis, examining the connection between organizational structures and strategies. Libraries are currently organized as information warehouses, and need to move toward organizations appropriate to information gateways. The present hierarchical structures do not accommodate self-managed teams. Those planning the transformation from information warehouse to information gateway must look to the future. They must plan and design flexible, adaptive structures based on shared values and norms.

Practical realities in the design/planning process were described by three librarians at differing points in the process. Deborah Babel described major changes made at Clemson a year ago and stressed that change is a continuing process. Clemson activities now focus on the user, not the function. Patron need is the overriding concern and Clemson staff look for continuous improvement

Cecilia Knight heads the staff team planning a user-centered organization at the University of Arizona. The design teams focus on direct access, mediated access, integrated access, and library support. Staff are being re-assigned based on the critical skills required in their new positions. The shared values center on team function and data-based decision making.

Marion Reid described the opportunity to start from scratch with a new library at the University of California at San Marcos. With no shared background, work focuses on service planning.

(continued on page 459)

\section{Order your Annual Conference audio cassette}

Audio cassettes of selected programs from the 1993 ALA Annual Conference in New Orleans are now available. Each program consists of two cassettes and sells for $\$ 24$ unless otherwise noted.

Leadership and Technological Change: A Call to Action Now ( $\$ 48$, four cassettes). Order no. ALA301

Standards at the Crossroads: The Accreditation Process and Library Standards. Order no. ALA304

Organizational Transformation: New Structures for New Realities. Order no. ALA310

To Be or Not To Be PC: An Overview of the Political Correctness Debate. Order no. ALA329

Danger in the Comfort Zone: Moving From Complacency to Productivity. Order no. ALA336

Coping with Chaos, Thriving on
Change: Redefining Bibliographic Instruction. Order no. ALA340

Technological Tabasco: Hot Ideas for Keeping Up with the Electronic Information Explosion. Order no. ALA356

Afro-American Information Resources: Assessing Three Decades of Progress 1960-1990. Order no. ALA359

Deep Leadership: Personal Empowerment and Organizational Effectiveness ( $\$ 12$, one cassette). Order no. AlA362

Headed for the Beach? Redirecting the Academic Whale. Order no. ALA367

Other programs are also available. Call, write, or fax your order or a request for a complete order form: Teach 'em, 160 East Illinois St., Chicago, IL 60611; voice: (312) 4670424, or (800) 225-3775; fax: (312) 467-9271. You may pay by check (payable to Teach 'em) or by credit card (VISA, MC, AMEX). 


\section{ULS in Now Orleans-preferred futures for librarians}

ULS was everywhere, doing almost everything in New Orleans. Our program, "Organizational Transformation: New Structures for New Realities is summarized on page 000 , but that was not all. Here are just a few highlights. Carol Hughes of the School of Information and Library Studies, University of Michigan, was the presenter June 27 for the Librarians in Higher Education and Campus Administration Discussion Group. Hughes talked about two workshops that brought together a diverse group of provosts/chief academic officers, directors of computing centers, faculty, staff, and library directors for the purpose of exchanging perceptions, viewpoints, and questions about the current and furure role of academic libraries.

Hughes used these workshops and a survey of chief academic officers and library directors at major U.S. universities, as a basis for her presentation.

The top four priorities, according to. Hughes, among provosts and chief academic officers were managing the budget, undergraduate education, building diversity, and working toward more provision of electronic information. Provosts want librarians to be risk takers, to be more proactive than reactive. Participants expressed interest in universal scholar workstation, but this interest varies by discipline. Others wanted to increase the library's education role, and wanted librarians to help faculty teach technology to under prepared students. Publishers advised librarians to stop thinking of libraries as warehouses and to emphasize access and cooperation.

\section{Meanwhile, the committees were hard at work}

While the discussions gathered great audiences, the committees were planning for the ongoing activities of the section. The Communications Committee completed work at long last on a membership brochure that will be seeing the light of day very soon.

Planning is under way for our $1994 \mathrm{An}$ nual Conference program, which promises to be another winner! The topic will be Network- ing for Leadership: A Mosaic of Opportunity. Some exciting speakers are expected, so look for this one next year in Miami.

The Current Topics Discussion Planning Committee is working on another provocative topic for Midwinter in Los Angeles. This year the topic is nothing if not current-Adjusting to Changing Library Organizational Structures. This will include the view from the other side-what do you do after the organization is transformed? It should be an interesting session.

The Executive Committee met and conducted several items of business, including the transfer of the section chair from Carolyn Robison, Georgia State University, to Noreen Aldredge, California State University, Hayward.

Many thanks to James Estrada who provided the summary of the higher education discussion group.-Mary Munroe, Georgia State University

\section{Academic Library Survey 1990 Institution Response and Statistical Norms}
- Number of Librarians, other Professionals
- Number of Support Staff
- Operating Expenditures
- Number of Holdings and Acquisitions
- Number of Transactions
- Library Services

Order Volume 1 of Response by all public twoand four-year institutions by name \$75 Print \$55 spreadsheet

$\$ 100$ Both

Order Volume 2 of Response by all private twoand four-year institutions by name

\$75Print \$55 spreadsheet

$\$ 100$ Both

Order Statistical Norms calculated for groups of institutions by Carnegie Classification, by region, by number of professionals, and more \$75 Print \$55 spreadsheet \$100 Both

Disks for PC or Mac (using PC Exchange)

Place your order by phone 1-800-444-8110 VISA, MasterCard, or Purchase Order John Minter Associates, Inc.

2400 Central Ave., B-2, Boulder CO 80301 


\section{Top priorities for ACRL-FY 1994}

ACRL provides programs, services, and resources to assist academic librarians in their effectiveness in the higher education community and prepare them to meet the information demands for the 1990 s and beyond. Thus far, leaders have identified these priorities:

\section{To participate effectively in the electronic} environment

- We are continuing to develop and expand use of the ACRL Listserv.

- We are supporting the work of a special task force to identify new areas of use and application for technology in academic libraries.

- We are conducting workshops and seminars to improve skills in the use of the Internet.

To seek input from members on their values/interests/priorities

- We are conducting a membership survey this fall.

- We are continuing the Midwinter planning session for ACRL members and leaders.

includes expenditures of $\$ 84,149$ for the 1995 ACRL National Conference and $\$ 23,371$ to support other member services. The ACRL fund balance at the beginning of FY1994 (which began September 1,1993 ) is $\$ 629,973$.

Approved modified language for chapter funding to reflect existing allocation patterns. Voted to fund the ACRL Speakers Bureau for FY1995 at \$3,500 and to expand the Speakers Bureau to include all board members and the executive director.

Approved Annual Conference program plan for FY1994.

Presented Cathleen Bourdon, former ACRL Deputy Executive Director with a "token of the Board's appreciation" (an elegant crystal desk/pen set engraved with her name and the inscription "ACRL Deputy Executive Director, 1983-1993") for ten years of service to ACRL.
To network with other ALA units, higher education, and other information-related organizations

- We are co-sponsoring programs with other ALA units.

- We are attending and participating in the programs of other associations.

- We are sharing publications and jointly sponsoring projects.

\section{To provide learning opportunities for members}

- We are supporting the National Conference, Annual Conference programs, and preconferences.

- We are maintaining a research and publications program.

- We are supporting programs at the local level through our chapters.

In addition, ACRL will continue to act on matters of advocacy: legislation, fees for service, information access; standards: Faculty Status for Librarians; information literacy; and diversity issues.

Agreed to establish a working group of the Board to examine the ACRL structure.

Established a task force of the Board to follow up on the recommendations from the Task Force on Underrepresented Minorities 1990 report to the Board.

(At the Crossroads continued from page 454)

In the change process, people interact in different ways with each other and with users. The change process generates a wide range of emotions - exhilaration, grief, fear, anger. These must be acknowledged and addressed.

Although there is a similarity with TQM in the customer/user driven emphasis and the focus on process. There is a difference in that libraries emphasize continuous adaptation, improvement, and evaluation.-Barbara Lockett, Rensselaer Polytechnic Institute 